\title{
The Influence of Ionic Liquids on Micellization of Sodium Dodecyl Sulfate in Aqueous Solutions
}

\author{
Bojan Šarac $^{\star}$ and Marija Bešter-Rogač \\ University of Ljubljana, Faculty of Chemistry and Chemical Technology, Večna pot 113, SI-1000 Ljubljana \\ ${ }^{*}$ Corresponding author: E-mail: bojan.sarac@fkkt.uni-lj.si
}

Received: 04-22-2020

\begin{abstract}
The micellization of sodium dodecyl sulfate (SDS) in water and in aqueous solutions of three imidazolium based ionic liquids with different side-chain length, i.e. 1,3-dimethylimidazolium chloride $\left(\left[\mathrm{C}_{1} \mathrm{mim}\right] \mathrm{Cl}\right), 1$-ethyl-3-methylimidazolium chloride $\left(\left[\mathrm{C}_{2} \mathrm{mim}\right] \mathrm{Cl}\right)$, and 1-butyl-3-methylimidazolium chloride $\left(\left[\mathrm{C}_{4} \mathrm{mim}\right] \mathrm{Cl}\right)$ was investigated by isothermal titration calorimetry (ITC) in the temperature range from 288.15 to $328.15 \mathrm{~K}$. For comparison, the micellization of SDS in the presence of $\mathrm{NaCl}$ was studied also. ITC experimental data were analysed by the two-state mass-action model, yielding the values of critical micelle concentration $(\mathrm{cmc})$, aggregation number $(n)$, standard heat capacity $\left(\Delta_{\mathrm{M}} c_{p}{ }^{\circ}\right)$, enthalpy $\left(\Delta_{\mathrm{M}} H^{\circ}\right)$, entropy $\left(\Delta_{\mathrm{M}} S^{\circ}\right)$, and Gibbs free energy $\left(\Delta_{\mathrm{M}} G^{\circ}\right)$ of the micellization process. It was found that the micellization of SDS in all the studied systems is an entropy-driven at lower temperatures and an enthalpy-driven at higher temperatures. In addition, it was assumed that with the increasing nonpolar character of IL, the interactions between the SDS are stronger, leading to more negative values of $\Delta_{\mathrm{M}} H^{\circ}$ and $\Delta_{\mathrm{M}} G^{\circ}$. To obtain more information about the micellar charge, the conductivity and zeta-potential measurements were performed at $298.15 \mathrm{~K}$. Presumably the micellar charge is more positive in the presence of ILs due to their stronger interaction and possible incorporation into the micellar structure. This reflects in less negative zeta-potential comparing to SDS in water and consequently higher degrees of micelle ionization due to the larger portion of sodium ions in solution.
\end{abstract}

Keywords: Sodium dodecyl sulfate; ionic liquids; isothermal titration calorimetry; thermodynamics; micelle ionization; zeta-potential

\section{Introduction}

Sodium dodecyl sulfate (SDS), also known as sodium lauryl sulfate (SLS), is a well-known anionic surfactant, widely used in cleaning and hygiene products, ${ }^{1}$ as a food additive $^{2}$ and also in research, as a cell disruptor, denaturating agent etc. ${ }^{3-5}$ It belongs to one of the most studied surfactants and consequently several characteristics of its micellization processes in aqueous solutions as, for example, the influence of inorganic electrolytes on critical micelle concentration $(\mathrm{cmc})$, the shape of micelles and thermodynamic parameters of micellization of SDS are well-known. ${ }^{6-12}$ However, the presence of organic electrolytes usually affects these parameters in much more dramatic way if their hydrophobic chains can penetrate the micelles, ${ }^{13}$ as was already observed for many other surfactant systems. ${ }^{14-20}$ For an investigation of these effects, ionic liquids (ILs) as the most studied organic electrolytes in the last decades ${ }^{21,22}$ seem to be the most appropriate. Because of their bulky cation and anion structure over which the charge is distributed by the resonance, they tend to be liquids at temperatures below $100^{\circ} \mathrm{C}$. Due to the amphiphilic character, some of the ILs can also be classified as catanionic hydrotropes, and they can enhance the solubility of hydrophobic compounds in water. ${ }^{23}$ Their behaviour in a pure state, mixtures or solutions is unlike conventional molecular solvents by forming amphiphilic nanostructures which offer great potential as designer solvents. ${ }^{24}$ Properties of many pure protic and aprotic ILs are already well-investigated, ${ }^{25-27}$ but the knowledge of their influence on aggregation process of SDS or any other surfactant is rather scarce. ${ }^{28-30}$ Beyaz et al., for example, showed that hydrophobic ILs (e.g. $30 \mathrm{mM}$ solution of 1-hexyl-3-methylimidazolium chloride $\left.\left(\left[\mathrm{C}_{6} \mathrm{mim}\right] \mathrm{Cl}\right)\right)$ decreased cmc of SDS, whereas hydrophilic ones (e.g. $30 \mathrm{mM}$ $\left[\mathrm{C}_{4} \mathrm{mim}\right] \mathrm{Cl}$ ) increased it. ${ }^{28}$ Such a trend was also obtained for SDS in solutions of 1-pentyl-3-methylimidazolium hexafluorophosphate $\left(\left[\mathrm{C}_{5} \mathrm{mim}\right]\left[\mathrm{PF}_{6}\right]\right)$, where $\mathrm{cmc}$ increased with increasing concentration of IL due to the solvophobic interactions around the surfactant hydrocarbon chains. ${ }^{29}$ On the contrary, Javadian et al. observed a 
decrease of $\mathrm{cmc}$ of SDS in up to $5.72 \mathrm{mM}$ of $\left[\mathrm{C}_{4} \mathrm{mim}\right] \mathrm{Cl}$. They also demonstrated that longer-chained ILs modify the structural properties of aggregates inducing the formation of wormlike micelles. It appears that the $\mathrm{cmc}$ values and morphology of the surfactant systems are strongly dependent upon the concentration and amphiphilicity of ILs which is still the area of extensive investigation. ${ }^{31,32}$

In the present work, the systematic study of the influence of the increasing hydrophobicity of ILs on the micellization process of SDS in aqueous solutions was carried out by using isothermal titration calorimetry (ITC), conductivity and zeta-potential measurements. Although SDS is one of the most studied surfactants, there is limited temperature-dependent data in the literature. Thus, the micellization of SDS in water was studied first, followed by the investigation of the micellization of SDS in the presence of three ILs, i.e. 1,3-dimethylimidazolium $\left(\left[\mathrm{C}_{1} \mathrm{mim}\right] \mathrm{Cl}\right)$, 1-ethyl-3-methylimidazolium $\left(\left[\mathrm{C}_{2} \mathrm{mim}\right] \mathrm{Cl}\right)$ and, 1-butyl-3-methylimidazolium chloride $\left(\left[\mathrm{C}_{4} \mathrm{mim}\right] \mathrm{Cl}\right)$, where the concentration of ILs was kept constant at $0.01 \mathrm{M}$. Because the comparison between ILs and "classical" electrolytes is always interesting and needed, we decided to include also the investigations of micellization of SDS in $\mathrm{NaCl}$ solutions. But it turned out, that $\mathrm{NaCl}$ affects the process in considerably less extend as ILs. Almost no difference between the thermodynamic parameters for micellization of SDS in water and in $0.01 \mathrm{M} \mathrm{NaCl}$ solution was found namely, so the experiments were performed in $0.1 \mathrm{M} \mathrm{NaCl}$ solutions. On the contrary, the effect of ILs on micellization of SDS is much stronger and already at the concentration of $0.01 \mathrm{M}$ the difference (in comparison to that in water) was considerable and compared to those in $0.1 \mathrm{M} \mathrm{NaCl}$ solutions.

Experimental ITC data were analysed by the twostate mass-action model yielding the corresponding standard thermodynamic parameters: Gibbs free energy $\left(\Delta_{\mathrm{M}} G^{\circ}\right)$, enthalpy $\left(\Delta_{\mathrm{M}} H^{\circ}\right)$, and entropy $\left(\Delta_{\mathrm{M}} S^{\circ}\right)$ of micellization together with $\mathrm{cmc}$ and aggregation number $(n)$. From conductivity measurements, we estimated a degree of micelle ionization $(\alpha)$ which will be discussed in the light of the determined zeta-potentials $(\zeta)$.

\section{Experimental}

\section{1. Chemicals}

Sodium dodecyl sulfate (purity $>98.5 \%, M=288.37$ $\mathrm{g} \mathrm{mol}^{-1}$ ) and sodium chloride (>99.5\%,M $=58.44 \mathrm{~g} \mathrm{~mol}^{-1}$ ) were purchased from Sigma-Aldrich (St. Louis, MO, USA) and used as received. 1,3-dimethyl- ( $>98 \%, M=132.59 \mathrm{~g}$ $\mathrm{mol}^{-1}$ ), 1-ethyl- (>98\%, $M=146.62 \mathrm{~g} \mathrm{~mol}^{-1}$ ) and 1-butyl-3-methylimidazolium chloride ( $>99 \%, M=174.67 \mathrm{~g}$ $\mathrm{mol}^{-1}$ ) were obtained from IoLiTec (Ionic Liquids Technologies $\mathrm{GmbH}$, Heilbronn, Germany) and used as received. The chemicals were stored in a desiccator over $\mathrm{P}_{2} \mathrm{O}_{5}$. For preparation of solutions, MiliQ water was used.

\section{2. Isothermal Titration Calorimetry}

The heat changes associated with (de)micellization of SDS were measured using a VP-ITC microcalorimeter (MicroCal Inc., Malvern, UK). The sample cell was filled with corresponding "solvent" (water, a solution of $0.1 \mathrm{M}$ $\mathrm{NaCl}$ or $0.01 \mathrm{M}$ of IL) and successive aliquots of $6 \mu \mathrm{L}$ of the surfactant solution, prepared in the same "solvent", were injected at 10-15 minutes intervals by a motor-driven syringe into the sample cell while stirring at $300 \mathrm{rpm}$. For each system, experiments at five temperatures between 288.15 and $328.15 \mathrm{~K}$ in step of $10 \mathrm{~K}$ were carried out. Each added aliquot produced a heat effect (raw signal) mainly due to the demicellization of surfactant micelles, dilution of monomers, and corresponding counterions. When the $\mathrm{cmc}$ of surfactant was exceeded in the sample cell, the heat effects evolved only due to dilution of micelles and ions. From the integration of the raw signal (an example in Figure S1a in Supporting information) the enthalpies of dilution $(\Delta H)$ of the surfactant expressed per mole of added SDS were obtained by using software Origin 7.0. According to our experience, the ITC gives highly reproducible results, thus, the experiments were not repeated.

\section{3. Conductivity Measurements}

Electrical conductivity of solutions was recorded with a PC-interfaced LCR Meter Agilent 4284 A connected to a three-electrode measuring cell described elsewhere. ${ }^{33}$ The cell constant was determined with dilute potassium chloride solutions. ${ }^{34}$ The cell was immersed in the high precision thermostat bath (containing polydimethylsiloxane) set to $298.15 \mathrm{~K}$. The temperature was additionally checked with a calibrated Pt100 resistance thermometer (MPMI 1004/300 Merz) connected to an HP 3458 A multimeter. ${ }^{33}$

After measuring the resistance of appropriate "solvent" (water, $0.1 \mathrm{M} \mathrm{NaCl}, 0.01 \mathrm{M} \mathrm{IL}$ ) at a set temperature, successive aliquots of a stock solution of the surfactant in the same "solvent" were added by a programmable syringe pump (Model 1250, J-KEM Scientific, MO, USA) and the resistance of the solution was measured. Afterwards, the specific conductivities were calculated using previously determined cell constant. The specific conductivities of solutions were corrected by the specific conductivities of "solvent" and plotted as a function of the molar concentration of SDS in the cell. From the slopes before and after the $\mathrm{cmc}$, the values of degree of micelle ionization $(\alpha)$ were estimated. ${ }^{35}$ The applied method for determination of electrical conductivity of solutions supplies highly reproducible data, thus, the experiments were not repeated.

\section{4. Zeta-Potential Determination}

Electrophoretic measurements were performed by Litesizer 500 (Anton Paar GmbH, Graz, Austria) in cuvette using Univette accessory. All the measurements were per- 
formed at $298.15 \mathrm{~K}$, after a 1-minute temperature equilibration period. For each solution, which was prepared directly in cuvette by diluting a stock solution of surfactant (20 $\mathrm{mM}$ ) with solvent, we performed 3 series (triplicates) of measurements, each containing 120 runs. All the zeta-potentials $(\zeta)$ were calculated using Smoluchowski approximation corrected by Henry: ${ }^{36,37}$

$$
\zeta=\frac{\mu \eta}{\varepsilon \varepsilon_{\mathrm{o}} f(\kappa a)}
$$

where $\mu$ is measured electrophoretic mobility, $\eta$ the viscosity of the medium, $\varepsilon$ the relative dielectric constant of the medium, $e_{\mathrm{o}}$ the vacuum permittivity, $\kappa$ the inverse of the Debye distance, and $a$ the radius of the micelles.

Function $f(k a)$ is for spherical micelles given by:

$$
f(\kappa a)=\frac{2}{3}\left[1+\frac{1}{2(1+2.5 / \kappa a\{1+2 \exp (-\kappa a)\})^{3}}\right]
$$

The viscosities and relative permittivities of all the solvents were taken the same as for the water $(0.890 \mathrm{mPa} \mathrm{s}$, 78.4). The radius of the micelles $a=1.81 \mathrm{~nm}$ for all investigated systems was taken. ${ }^{38}$

\section{Thermodynamics of Micellization}

According to the two-state mass-action model, the process of micellization of SDS can be described as the equilibrium between negatively charged surfactant monomers $\left(\mathrm{S}^{-}\right)$, corresponding positive counterions $\left(\mathrm{C}^{+}\right)$, and micelles $\left(\mathrm{M}^{\alpha n-}\right)$ :

$$
n \mathrm{~S}^{-}+n(1-\alpha) \mathrm{C}^{+} \stackrel{K_{M}}{\rightleftarrows} \mathrm{M}^{\alpha_{-}}
$$

where $n$ represents the aggregation number and $\alpha$ the degree of micelle ionization. The apparent constant of micellization $\left(K_{\mathrm{M}}\right)$ expressed by the molalities of corresponding species, can be connected to the Gibbs free energy of micellization $\left(\Delta_{\mathrm{M}} G^{\circ}\right)$ by:

$$
\Delta_{\mathrm{M}} G^{\circ}=-\frac{R T}{n} \ln K_{\mathrm{M}}=-\frac{R T}{n} \ln \frac{m_{\mathrm{M}}}{m_{\mathrm{S}}^{n}\left(m_{\mathrm{C}}+m_{\mathrm{X}}\right)^{n(1-\alpha)}}
$$

where $m_{\mathrm{X}}$ represents the molality of added electrolyte $(0.1$ $\mathrm{M} \mathrm{NaCl}$ or $0.01 \mathrm{M} \mathrm{IL}$ ).

By ITC experiment, the heat effects accompanying the titration of stock solution in the sample cell are measured, presented usually in form so called enthalpograms as the enthalpy of dilution $(\Delta H)$ versus the concentration of surfactant in the solution (Figure S1b). $\Delta H$ can be expressed in terms of partial molar enthalpies of surfactant $\left(\bar{H}_{\mathrm{s}}\right)$, counterions $\left(\bar{H}_{\mathrm{c}}\right)$ and the enthalpy of micellization $\left(\Delta_{\mathrm{M}} H^{\circ}\right)$ by the use of thermodynamic laws and mass-balance equations as: ${ }^{39}$

$$
\Delta H=\left(\bar{H}_{\mathrm{S}}+\bar{H}_{\mathrm{C}}\right)+\Delta_{\mathrm{M}} H^{\circ}\left(\frac{\partial n_{\mathrm{M}}}{\partial n_{2}}\right)_{m_{1}, p, T}
$$

where the last term represents the change of the amount of surfactant in the micellar form at every addition of surfactant and is connected to $K_{\mathrm{M}}$ or $\Delta_{\mathrm{M}} G^{\mathrm{o}} . \bar{H}_{\mathrm{s}}$ and $\bar{H}_{\mathrm{c}}$ were determined from the extrapolation of the lines through the plateaus of the enthalpograms before the $\mathrm{cmc}$, as it is shown on Figure S1b. $\Delta_{\mathrm{M}} H^{\mathrm{o}}$ and $\Delta_{\mathrm{M}} G^{\mathrm{o}}$ were the fitting parameters primarily determined at $298.15 \mathrm{~K}$ (reference temperature, $\left.T_{\mathrm{o}}\right)$. At other temperatures $(T)$, their values were obtained from the Kirchhoff and integrated Gibbs-Helmholtz equations

$$
\begin{aligned}
\Delta_{\mathrm{M}} H^{\mathrm{o}}(T)= & \Delta_{\mathrm{M}} H^{\mathrm{o}}\left(T_{\mathrm{o}}\right)+\Delta_{\mathrm{M}} c_{p}^{\mathrm{o}} \cdot\left(T-T_{\mathrm{o}}\right) \\
\Delta_{\mathrm{M}} G^{\mathrm{o}}(T)= & T\left(\Delta_{\mathrm{M}} G^{\mathrm{o}}(T) / T_{\mathrm{o}}+\Delta_{\mathrm{M}} H^{\mathrm{o}}(T) \cdot\left[1 / T-1 / T_{\mathrm{o}}\right]+\right. \\
& +\Delta_{\mathrm{M}} c_{p}^{\mathrm{o}} \cdot\left[1-T / T_{\mathrm{o}}-\ln \left(T / T_{\mathrm{o}}\right)\right]
\end{aligned}
$$

where $\Delta_{\mathrm{M}} c_{p}{ }^{\circ}$ was treated as a temperature-independent fitting parameter.

The model function (right-hand side of equation (5)) was fitted to the ITC experimental data simultaneously at all temperatures (global fitting), using the Levenberg-Marquardt nonlinear regression algorithm. ${ }^{40}$ A detailed derivation of equation (5) is given in our previous work. ${ }^{39}$ From the global analysis of ITC data, the best-fit thermodynamic parameters were extracted, i.e., enthalpy, $\Delta_{\mathrm{M}} H^{\circ}$, Gibbs free energy, $\Delta_{\mathrm{M}} G^{\mathrm{o}}$, and heat capacity, $\Delta_{\mathrm{M}} c_{p}{ }^{\mathrm{o}}$, of the micellization. Aggregation number $(n)$ was set as the temperature-independent fitting parameter during the global analysis. The values of $\alpha$ were estimated from conductivity measurements at $298.15 \mathrm{~K}$. Since the values of fitting parameters in the ITC data analysis are not correlated strongly to $\alpha$, it was taken as a temperature-independent parameter. The entropy of micellization was calculated from the Gibbs-Helmholtz equation

$$
\Delta_{\mathrm{M}} S^{\mathrm{o}}=\frac{\Delta_{\mathrm{M}} H^{\circ}-\Delta_{\mathrm{M}} G^{\mathrm{o}}}{T}
$$

\section{Results and Discussion}

The dependence of experimental enthalpy of dilution $(\Delta H)$ on surfactant concentration (enthalpogram) for titration of SDS in water from $288.15 \mathrm{~K}$ to $328.15 \mathrm{~K}$ is shown in Figure 1a. The precipitation of SDS (Krafft point) at $278.15 \mathrm{~K}$ takes place immediately after the $\mathrm{cmc}$ in the sample cell is reached (Figure S2 in Supporting information), therefore this temperature was excluded from the temperature range in further experiments. Enthalpograms for titration of SDS in $0.1 \mathrm{M} \mathrm{NaCl}$ and $0.01 \mathrm{M}$ solutions of $\left[\mathrm{C}_{1} \mathrm{mim}\right] \mathrm{Cl},\left[\mathrm{C}_{2} \mathrm{mim}\right] \mathrm{Cl}$ and $\left[\mathrm{C}_{4} \mathrm{mim}\right] \mathrm{Cl}$ in the investigated temperature range are presented in Figure S3 in Supporting information. 
The comparison of enthalpograms for the micellization process of SDS in all studied systems at $308.15 \mathrm{~K}$ is shown in Figure 1b. From Figures 1 and S3 in Supporting information, it is evident, that the energetics of the micellization process is highly dependent on the temperature and a type and/or concentration of added electrolyte. As explained already in Introduction, the impact of lower concentrations of $\mathrm{NaCl}$ (e.g. $0.01 \mathrm{M})^{12}$ on the micellization process of SDS is less pronounced in terms of $\mathrm{cmc}$ and thermodynamic parameters comparing to investigated ILs, therefore all experiments were performed in $0.1 \mathrm{M}$ $\mathrm{NaCl}$ solutions. Resulting $\mathrm{cmc}$ values are similar comparing to 10-times less concentrated solutions of ILs which furthermore emphasize the effect of organic additives on micellization process.

By applying the global fitting of the model equation (5) to the experimental ITC data, denoted on the graphs as full lines, the values of $\Delta_{\mathrm{M}} H^{\mathrm{o}}, \Delta_{\mathrm{M}} G^{\mathrm{o}}, \Delta_{\mathrm{M}} c_{p}{ }^{\mathrm{o}}$, and $n$ were obtained as the best fitting parameters. $\Delta_{\mathrm{M}} S^{\mathrm{o}}$ was calculated by help of equation (7), whereas the $\mathrm{cmc}$ values were determined from the inflection point of the fitting curves. All estimated parameters at $298.15 \mathrm{~K}$ are listed in Table 1 , together with available literature data. In Table S1 in Supporting information also the data at other temperatures are gathered.

The temperature dependence of $\mathrm{cmc}$ for SDS in all investigated systems shows nearly U-shaped form (Figure 2a). Evidently, cmc is systematically decreasing by increasing polarity of counterions from $\left[\mathrm{C}_{1} \mathrm{mim}\right] \mathrm{Cl}$ to $\left[\mathrm{C}_{4} \mathrm{mim}\right]$ $\mathrm{Cl}$. Our results are in agreement with the findings of Javadian et al., ${ }^{30}$ but Beyaz et al. reported a higher value of $\mathrm{cmc}$ in solution of $30 \mathrm{mM}$ of $\left[\mathrm{C}_{4} \mathrm{mim}\right] \mathrm{Cl}^{28}$ The $\mathrm{cmc}$ values in water and $0.1 \mathrm{M} \mathrm{NaCl}$ agree quite well with available ITC literature data (see Table 1 for an overview). $8,12,41$

The smallest aggregation number $(n$, Table 1$)$ for the micelles of SDS in water was found. In the presence of ILs the micelles should be slightly bigger, but the structure of ILs does not have an expressed influence on $n$. For SDS in $0.1 \mathrm{M} \mathrm{NaCl}$ aqueous solutions the highest $n$ was estimated, supporting the reported sphere-rod transition. ${ }^{42,43}$
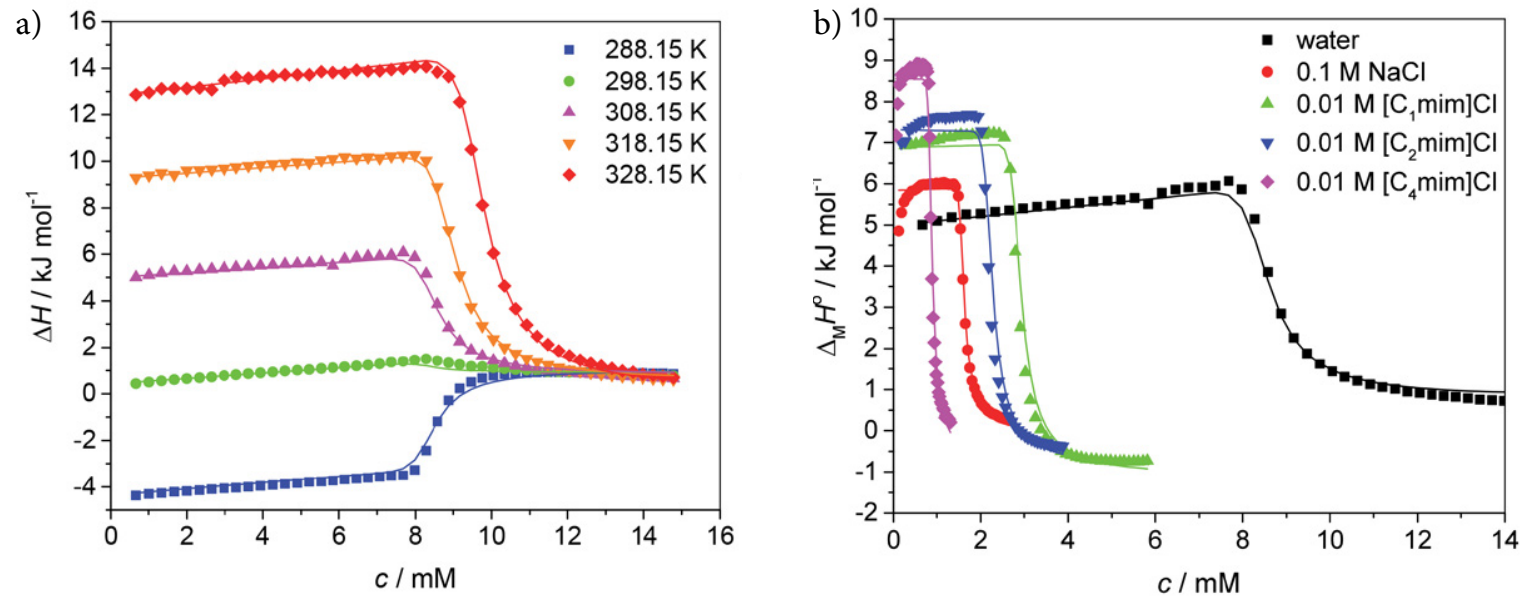

Figure 1. (a) Enthalpograms of SDS titrations in water from $288.15 \mathrm{~K}$ to $328.15 \mathrm{~K}$ in the step of $10 \mathrm{~K}$ and (b) enthalpograms of SDS in all investigated systems at $308.15 \mathrm{~K}$. Symbols represent the experimental data, and solid lines are the best-fits according to two-state mass action model (eq. (5)).
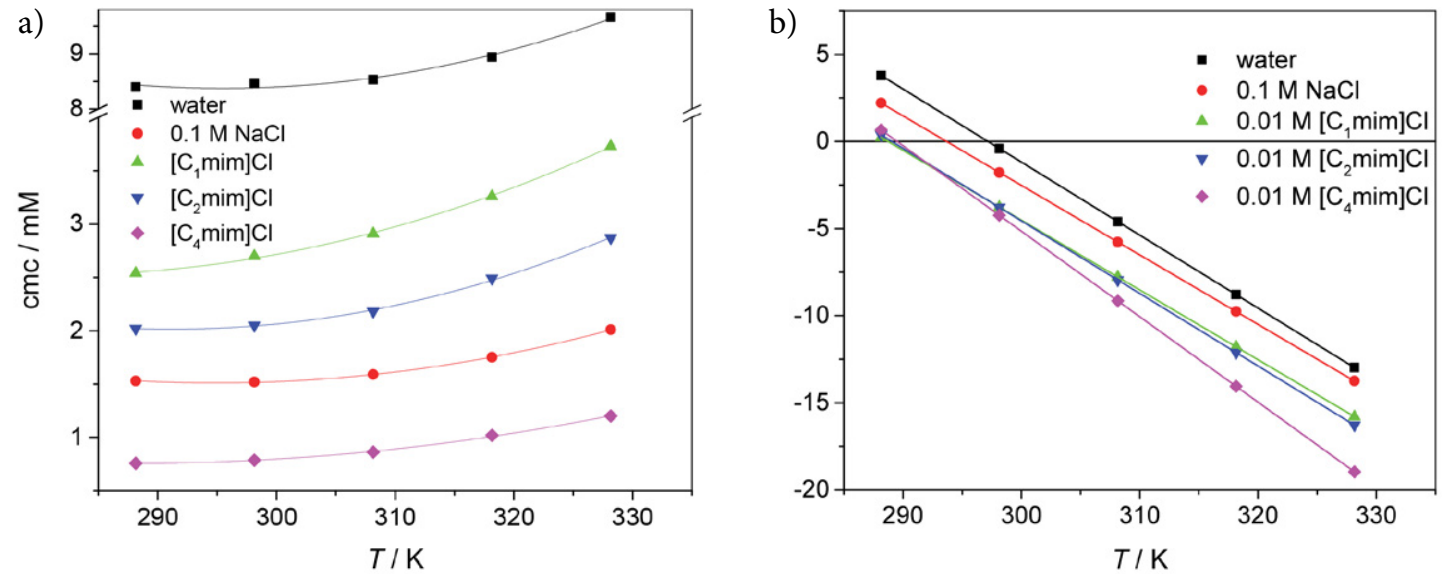

Figure 2. (a) The values of $\mathrm{cmc}$ and (b) $\Delta_{\mathrm{M}} H^{\mathrm{o}}$ as a function of temperature for all investigated systems. Lines in (a) present guides to the eye (polynomial fits) and in (b) linear fits from which the heat capacities of micellization were extracted. 
The micellization process is endothermic at low temperatures and exothermic at higher temperatures, as it is evident from Figure $2 \mathrm{~b}$ and Table $\mathrm{S} 1$ in Supporting information. Similar behaviour has already been observed at micellization process of alkyltrimethylammonium chlorides in water and aqueous solutions of $\mathrm{NaCl}$ or hydroxybenzoates. ${ }^{17,19,44,45}$ Evidently, the temperature at which $\Delta_{\mathrm{M}} H^{0}=0$ is $\sim 297 \mathrm{~K}$ for SDS in water and $\sim 290 \mathrm{~K}$ in the presence of ILs. The change in the sign of $\Delta_{\mathrm{M}} H^{\circ}$ is related to the sensitive balance between the main two processes accompanying the micellization: (de)hydration of nonpolar parts of surfactants' monomers, which are then held together by cooperative noncovalent interactions, and condensation of counterions onto the micellar surface upon the micellization. The first process is energetically unfavourable (endothermic), and it is prevailing at lower temperatures, whereas the condensation of counterions is an exothermic process and only weakly temperature-dependent. With increasing temperature- as a consequence of increasing thermal energy in the systems- the binding of surrounding water molecules to the nonpolar parts is weaker leading to the overall exothermic process of micellization.

Gibbs free energy $\left(\Delta_{\mathrm{M}} G^{\circ}\right)$ of the micellization process of SDS is negative in all studied systems, as it is characteristically for spontaneous processes (Table 1). From Table 1 in Supporting information is evident, that the micellization of SDS in all media is entropically driven process at lower temperatures whereas at higher temperatures the entropy and enthalpy contribute both to the negative value of $\Delta_{\mathrm{M}} G^{\circ}$ as it is usually found for ionic surfactants. ${ }^{45-49}$ The main contribution to the entropy change stems from desolvation of the cations and anions upon the micellization, which is obviously comparable among the investigated systems, leading to only small differences in $T \Delta_{M} S^{\circ}$. Furthermore, the last diminishes with temperature, due to rising thermal energy of the water molecules, leading to the prevalence of enthalpy $\left(\Delta_{\mathrm{M}} H^{\circ}\right)$ connected to the electrostatic interactions between the positive counterions and negative sulfate heads.

The values of $\Delta_{\mathrm{M}} \mathcal{c}_{\mathrm{p}}{ }^{\mathrm{o}}$ for studied micellization process of SDS in different media are strongly negative, which is characteristic for the processes at removal of water surrounding nonpolar chains upon the micellization. The largest value (in the absolute sense) is obtained for SDS in $\left[\mathrm{C}_{4} \mathrm{mim}\right] \mathrm{Cl}$ solution. Since the most expressed nonpolar character of $\left[\mathrm{C}_{4} \mathrm{mim}\right]^{+}$cation, it can be assumed that the butyl chain is partly dehydrated and incorporated into the micellar structure. The interactions (noncovalent and electrostatic) between the SDS and ILs are therefore rising with the increasing length of the nonpolar chain which is also evident from the increasing exothermicity of the micellization process $\left(\Delta_{\mathrm{M}} H^{\circ}\right)$ at a fixed temperature (Tables 1 and S2).

The value of $\alpha$ is in $0.1 \mathrm{M} \mathrm{NaCl}$ higher than in water which was already observed for SDS and also DTAC in high salinity systems and can be attributed to increased charge screening in a diffuse layer around micelles at higher ionic strength. ${ }^{7,50}$ In the presence of 0.01 M ILs the values of $\alpha$ are also higher than in water and are interestingly rising in the order from $\left[\mathrm{C}_{1} \mathrm{mim}\right] \mathrm{Cl}$ to $\left[\mathrm{C}_{4} \mathrm{mim}\right] \mathrm{Cl}$. With the assumption that the contribution of the micelles to the specific conductivity of solutions is negligible, the slopes of specific conductivities before and after the $\mathrm{cmc}$, from which the $\alpha$ values were determined, depend mainly upon the mobility of small ions, ${ }^{51}$ such as $\mathrm{Na}^{+}$and IL cations in

Table 1. The values of critical micelle concentration ( $\mathrm{cmc}$ ), aggregation number $(n)$, enthalpy $\left(\Delta_{\mathrm{M}} H^{\circ}\right)$, Gibbs free energy $\left(\Delta_{\mathrm{M}} G^{\circ}\right)$, entropy contribution $\left(T \Delta_{\mathrm{M}} S^{\circ}\right)$, heat capacity $\left(\Delta_{\mathrm{M}} c_{\mathrm{p}}{ }^{\circ}\right)$ of micellization, and a degree of micelle ionization $(\alpha)$ for SDS in all the investigated systems at $298.15 \mathrm{~K}$. Where possible, the literature data are given (the numbers in parentheses denote the temperature at which the values were determined). ${ }^{a}$

\begin{tabular}{|c|c|c|c|c|c|}
\hline & Water & $0.1 \mathrm{M} \mathrm{NaCl}$ & $0.01 \mathrm{M}\left[\mathrm{C}_{1} \mathrm{mim}\right] \mathrm{Cl}$ & $0.01 \mathrm{M}\left[\mathrm{C}_{2} \mathrm{mim}\right] \mathrm{Cl}$ & $0.01 \mathrm{M}\left[\mathrm{C}_{4} \mathrm{mim}\right] \mathrm{Cl}$ \\
\hline $\mathrm{cmc}$ & $\begin{array}{c}8.47 \pm 0.04 \\
8.1(301 K)^{b} \\
8.73(293 K)^{c}\end{array}$ & $\begin{array}{c}1.52 \pm 0.01 \\
1.54^{\mathrm{b}} \\
1.72(303 \mathrm{~K})^{\mathrm{d}}\end{array}$ & $2.70 \pm 0.04$ & $2.05 \pm 0.03$ & $0.79 \pm 0.01$ \\
\hline$n$ & $24 \pm 1$ & $42 \pm 1$ & $30 \pm 1$ & $29 \pm 1$ & $30 \pm 2$ \\
\hline$\Delta_{\mathrm{M}} H^{\mathrm{o}}$ & $\begin{array}{c}-0.40 \pm 0.06 \\
0.22^{\mathrm{b} \star} \\
-0.82^{\mathrm{c} *} \\
-0.81^{\mathrm{e}}\end{array}$ & $\begin{array}{c}-1.78 \pm 0.04 \\
-1.90(301 \mathrm{~K})^{\mathrm{b}}\end{array}$ & $-3.77 \pm 0.06$ & $-3.78 \pm 0.05$ & $-4.24 \pm 0.08$ \\
\hline$\Delta_{\mathrm{M}} G^{\mathrm{o}}$ & $-18.04 \pm 0.03$ & $-16.97 \pm 0.06$ & $-19.00 \pm 0.01$ & $-19.23 \pm 0.01$ & $-21.57 \pm 0.05$ \\
\hline$T \Delta_{M} S^{o}$ & $17.64 \pm 0.07$ & $15.19 \pm 0.08$ & $15.24 \pm 0.07$ & $15.45 \pm 0.05$ & $17.33 \pm 0.09$ \\
\hline$\Delta_{\mathrm{M}} c_{\mathrm{p}}{ }^{\mathrm{o}}$ & $-0.419 \pm 0.004$ & $-0.399 \pm 0.004$ & $-0.401 \pm 0.004$ & $-0.417 \pm 0.002$ & $-0.491 \pm 0.005$ \\
\hline$\alpha$ & $0.379 \pm 0.005$ & $0.70 \pm 0.05$ & $0.496 \pm 0.007$ & $0.536 \pm 0.003$ & $0.549 \pm 0.007$ \\
\hline
\end{tabular}

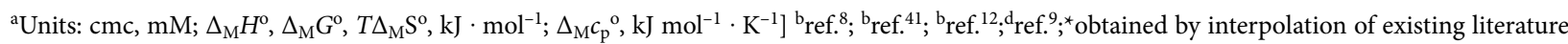
data 
our case. Due to the partial nonpolar (hydrophobic) character, IL cations interact more strongly with sulfate headgroups of SDS than $\mathrm{Na}^{+}$ions. Consequently, the micellar surface potential is lower leading to the lower condensation of $\mathrm{Na}^{+}$ions on the micellar surface than in water. In other words, a larger portion of $\mathrm{Na}^{+}$ions are free in the bulk, which gives rise to the $\alpha$ values.

To affirm such a hypothesis and to gain insight into the micellar charge, we performed $\zeta$-potential measurements. Figure 3 shows the values of $\zeta$-potential as a function of SDS concentration in water, $0.1 \mathrm{M} \mathrm{NaCl}$, and 0.01 $\mathrm{M}$ IL solutions. Our values for SDS in water and 0.1 M $\mathrm{NaCl}$ correspond well to the literature data (around -100 $\mathrm{mV}$ and $-60 \mathrm{mV}$, respectively), ${ }^{12,}{ }^{52}$ whereas for SDS in IL solutions no data was found. From Figure 3, it is evident that the values of $\zeta$-potential after $\mathrm{cmc}$ in $0.01 \mathrm{M} \mathrm{IL}$ and 0.1 $\mathrm{M} \mathrm{NaCl}$ solutions are less negative (or more positive) than in water. This can be attributed to the lower micellar charge, due to possible incorporation of IL cations, or more efficient screening around SDS micelles. On the other hand, the least negative value of $\zeta$-potential was encountered for $\left[\mathrm{C}_{2} \mathrm{mim}\right] \mathrm{Cl}$, which is somewhat surprising. $\zeta$-potential is an experimentally determined potential (or electrical charge) of micelles within the region to some distance from the micellar surface, also abbreviated as a shear plane. The difference in the values between ILs could be prescribed to the shifting of the position of the shear plane due to their different depths of incorporation into the micellar structure. Probably the $\left[\mathrm{C}_{4} \mathrm{mim}\right]^{+}$cation is incorporated more deeply than $\left[\mathrm{C}_{2} \mathrm{mim}\right]^{+}$cation meaning that imidazolium ring of the last is farther from the micellar surface. Therefore, the shear plane is extended towards the bulk solution leading to less negative $\zeta$-potential. Interestingly, the $\zeta$-potential for SDS in $\left[\mathrm{C}_{1} \mathrm{mim}\right] \mathrm{Cl}$ is similar as in $\left[\mathrm{C}_{4} \mathrm{mim}\right] \mathrm{Cl}$. The possible explanation for this could be a different orientation of $\left[\mathrm{C}_{1} \mathrm{mim}\right]^{+}$cation at the micellar surface since the cation is more symmetrical than the oth-

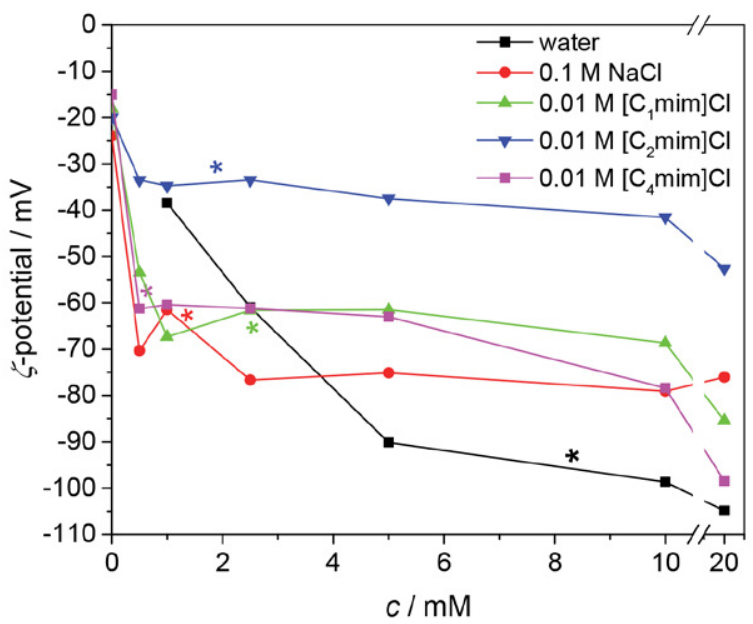

Figure 3. $\zeta$-potential values for all investigated systems as a function of SDS concentration at $298.15 \mathrm{~K}$. Asterisks denote the corresponding $\mathrm{cmc}$ values. er two, but this needs further investigation. It is also interesting that after $\mathrm{cmc}$ all the $\zeta$-potential values are monotonically decreasing with SDS concentration except in the case of SDS in $0.1 \mathrm{M} \mathrm{NaCl}$ solutions where it is almost constant throughout the whole concentration range of SDS. Here it has to be emphasized that at high concentrations of the additives the SDS could form cylindrical or rod-like micelles $^{42,43}$ which makes the interpretation of $\zeta$-potential dubious and needs further exploration. For example, if we employ function $f(k a)$ for cylindrical micelles ${ }^{36}$ in equation (1) we obtain $\zeta$-potential around $-100 \mathrm{mV}$ for $20 \mathrm{mM}$ SDS in $0.1 \mathrm{M} \mathrm{NaCl}$.

\section{Conclusions}

The micellization process of SDS in water, $0.1 \mathrm{NaCl}$, and $0.01 \mathrm{M}$ solutions of $\left[\mathrm{C}_{1} \mathrm{mim}\right] \mathrm{Cl},\left[\mathrm{C}_{2} \mathrm{mim}\right] \mathrm{Cl}$, and $\left[\mathrm{C}_{4} \mathrm{mim}\right] \mathrm{Cl}$ was studied from 288.15 to $328.15 \mathrm{~K}$ using ITC. From the fitting of the model equation from twostate mass-action model to the ITC experimental data the thermodynamic parameters - enthalpy $\left(\Delta_{\mathrm{M}} H^{\circ}\right)$, Gibbs free energy $\left(\Delta_{\mathrm{M}} G^{\circ}\right)$, entropy $\left(\Delta_{\mathrm{M}} S^{\circ}\right)$, heat capacity $\left(\Delta_{\mathrm{M}} c_{p}{ }^{\circ}\right)$, critical micelle concentrations $(\mathrm{cmc})$ and aggregation numbers $(n)$ - were determined. The micellization of SDS is a spontaneous (negative $\Delta_{\mathrm{M}} G^{\mathrm{o}}$ values) and entropically driven process at lower temperatures whereas at higher temperatures, $\Delta_{\mathrm{M}} H^{\circ}$ becomes prevalent. The spontaneity is more expressed in the case of SDS in ionic liquids (ILs) solutions which is also reflected in lower $\mathrm{cmc}$ values than in water. The same can also be observed for SDS in $0.1 \mathrm{M} \mathrm{NaCl}$. In the last case, we also observed higher $n$ than at others which could be due to the formation of rod-like micelles.

The values of $\alpha$ were estimated from conductivity measurements at $298.15 \mathrm{~K}$ in all investigated systems. Interestingly, we observed the increase of $\alpha$ values in the case of added electrolytes. Furthermore, zeta-potential $(\zeta)$ of micelles at different concentrations of SDS was determined at $298.15 \mathrm{~K}$. It turned out that all the values are less negative than in water. This can be attributed to the condensation and partial incorporation of IL cations to the micelle surface and consequently lowering the micelle surface potential. In this way, the charge of the micelles is lower than in the water, where $\mathrm{Na}^{+}$ions are the only counterions, which leads to a greater portion of the last ions in the bulk and consequently higher $\alpha$ values.

\section{Acknowledgements}

The financial support by the Slovenian Research Agency through Grant No. P1-0201 is gratefully acknowledged. The authors would also like to thank Ph. D. student Nevena Đekić for her help at the laboratory work. 


\section{References}

1. C. A. Bondi, J. L. Marks, L. B. Wroblewski, H. S. Raatikainen, S. R. Lenox, K. E. Gebhardt, Environ. Health Insights 2015, 9, 27-32. DOI:10.4137/EHI.S31765

2. S. R. Igoe, Dictionary Of Food Ingredients, Springer, San Diego, USA, 2011, pp. 131.

DOI:10.1007/978-1-4419-9713-5

3. H. Schägger, in: C. Hunte, G. von Jagow and H. Schägger (Eds.): Membrane Protein Purification and Crystallization, Elsevier, Amsterdam, Netherlands, 2003, pp. 85-103.

DOI:10.1016/B978-0-12-361776-7.X5000-1

4. R. E. Farrell, RNA Methodologies, Elsevier, Amsterdam, Netherlands, 2010, pp. 155-172.

DOI:10.1016/B978-0-12-374727-3.00007-3

5. K. T. Naidu, N. P. Prabhu, J. Phys. Chem. B 2011, 115, 1476014767. DOI:10.1021/jp2062496

6. G. C. Kresheck, W. A. Hargraves, J. Colloid Interface Sci. 1974, 48, 481-493. DOI:10.1016/0021-9797(74)90193-3

7. P. C. Shanks, E. I. Franses, J. Phys. Chem. 1992, 96, 1794-1805. DOI:10.1021/j100183a055

8. S. Paula, W. Sus, J. Tuchtenhagen, A. Blume, J. Phys. Chem. 1995, 99, 11742-11751. DOI:10.1021/j100030a019

9. A. Chatterjee, S. P. Moulik, S. K. Sanyal, B. K. Mishra, P. M. Puri, J. Phys. Chem. B 2001, 105, 12823-12831.

DOI:10.1021/jp0123029

10. E. Dutkiewicz, A. Jakubowska, Colloid Polym. Sci. 2002, 280, 1009-1014. DOI:10.1007/s00396-002-0723-y

11. R. F. P. Pereira, A. J. M. Valente, H. D. Burrows, J. Mol. Liq. 2010, 156, 109-114. DOI:10.1016/j.molliq.2010.02.007

12. B. Naskar, A. Dey, S. P. Moulik, J. Surfactants Deterg. 2013, 16, 785-794. DOI:10.1007/s11743-013-1449-1

13. B. C. Paul, S. S. Islam, K. Ismail, J. Phys. Chem. B 1998, 102, 7807-7812. DOI:10.1021/jp9812381

14. C. Manohar, U. R. K. Rao, B. S. Valaulikar, R. M. Lyer, J. Chem. Soc., Chem. Commun. 1986, 379-381.

DOI:10.1039/c39860000379

15. L. J. Magid, Z. Han, G. G. Warr, M. A. Cassidy, P. D. Butler, W. A. Hamilton, J. Phys. Chem. B 1997, 101, 7919-7927. DOI:10.1021/jp970864f

16. K. Bijma, M. J. Blandamer, J. B. F. N. Engberts, Langmuir 1998, 14, 79-83. DOI:10.1021/la970216n

17. B. Šarac, J. Cerkovnik, B. Ancian, G. Mériguet, G. M. Roger, S. Durand-Vidal, M. Bešter-Rogač, Colloid Polym. Sci. 2011, 289, 1597-1607. DOI:10.1007/s00396-011-2480-2

18. T. K. Hodgdon, E. W. Kaler, Curr. Opin. Colloid Interface Sci. 2007, 12, 121-128. DOI:10.1016/j.cocis.2007.06.004

19. B. Šarac, G. Meriguet, B. Ancian, M. Bešter-Rogač, Langmuir 2013, 29, 4460-4469. DOI:10.1021/la400161n

20. I. Čobanov, B. Šarac, Ž. Medoš, A. Tot, M. Vraneš, S. Gadžurić, M. Bešter-Rogač, J. Mol. Liq. 2020, 301, 112419.

DOI:10.1016/j.molliq.2019.112419

21. T. Welton, Biophys. Rev. 2018, 10, 691-706.

DOI:10.1007/s12551-018-0419-2

22. M. Bešter-Rogač, Acta Chim. Slov. 2020, 67, 1-14. DOI:10.17344/acsi.2020.5870
23. A. F. M. Claudio, M. C. Neves, K. Shimizu, J. N. C. Lopes, M. G. Freire, J. A. P. Coutinho, Green Chem. 2015, 17, 3948-3963. DOI:10.1039/C5GC00712G

24. H. J. Jiang, R. Atkin, G. G. Warr, Curr. Opin. Green Sustain. Chem. 2018, 12, 27-32. DOI:10.1016/j.cogsc.2018.05.003

25. R. Hayes, G. G. Warr, R. Atkin, Chem. Rev. 2015, 115, 63576426. DOI: $10.1021 / \mathrm{cr} 500411 \mathrm{q}$

26. S. Zhang, N. Sun, X. He, X. Lu, X. Zhang, J. Phys. Chem. Ref. Data 2006, 35, 1475-1517. DOI:10.1063/1.2204959

27. T. L. Greaves, A. Weerawardena, C. Fong, C. J. Drummond, Langmuir 2007, 23, 402-404. DOI:10.1021/la062895k

28. A. Beyaz, W. S. Oh, V. P. Reddy, Colloids Surf., B 2004, 35, 119-124. DOI:10.1016/j.colsurfb.2004.02.014

29. A. Pal, S. Chaudhary, Colloids Surf., A 2013, 430, 58-64. DOI:10.1016/j.colsurfa.2013.04.001

30. S. Javadian, F. Nasiri, A. Heydari, A. Yousefi, A. A. Shahir, J. Phys. Chem. B 2014, 118, 4140-4150.

DOI:10.1021/jp5010049

31. M. T. Lam, W. D. Adamson, S. Miao, R. Atkin, G. G. Warr, J. Colloid Interface Sci. 2019, 552, 597-603.

DOI:10.1016/j.jcis.2019.05.082

32. S. J. Bryant, C. J. Jafta, R. Atkin, M. Gradzielski, G. G. Warr, J. Colloid Interface Sci. 2019, 540, 515-523.

DOI:10.1016/j.jcis.2019.01.048

33. M. Bešter-Rogač, D. Habe, Acta Chim. Slov. 2006, 53, 391395.

34. J. Barthel, F. Feuerlein, R. Neueder, R. Wachter, J. Solution Chem. 1980, 9, 209-219. DOI:10.1007/BF00648327

35. J. P. Marcolongo, M. Mirenda, J. Chem. Educ. 2011, 88, 629633. DOI:10.1007/BF00648327

36. M. A. Morini, P. C. Schulz, Colloid Polym. Sci. 1997, 275, 802-805. DOI:10.1007/s003960050151

37. D. C. Henry, Proc. R. Soc. Lond. A 1931, 133, 106-129. DOI:10.1098/rspa.1931.0133

38. M. Almgren, S. Swarup, J. Phys. Chem. 1982, 86, 4212-4216. DOI:10.1021/j100218a024

39. A. Kroflič, B. Šarac, M. Bešter-Rogač, Langmuir 2012, 28, 10363-10371. DOI:10.1021/la302133q

40. W. H. Press, S. A. Teukolsky, W. T. Vetterling, B. P. Flannery, Numerical Recipes in Fortran 77: The Art of Scientific Computing, Cambridge University Press, New York, 2001, pp. 678

41. P. R. Majhi, A. Blume, Langmuir 2001, 17, 3844-3851. DOI:10.1021/la001660k

42. A. Coello, F. Meijide, M. A. Mougán, E. Núñez Rodríguez, J. Tato Vázquez, J. Chem. Educ. 1995, 72, 73-75.

DOI:10.1021/ed072p73

43. S. Hayashi, S. Ikeda, J. Phys. Chem. 1980, 84, 744-751. DOI:10.1021/j100444a011

44. T. M. Perger, M. Bešter-Rogač, J. Colloid Interface Sci. 2007, 313, 288-295. DOI:10.1016/j.jcis.2007.04.043

45. B. Šarac, M. Bešter-Rogač, J. Colloid Interface Sci. 2009, 338, 216-221. DOI:10.1016/j.jcis.2009.06.027

46. K. Beyer, D. Leine, A. Blume, Colloids Surf., B 2006, 49, 31-39. DOI:10.1016/j.colsurfb.2006.02.003

47. R. Zielinski, J. Colloid Interface Sci. 2001, 235, 201-209. DOI: $10.1006 /$ jcis.2000.7364 
48. A. Kroflič, B. Šarac, M. Bešter-Rogač, J. Chem. Thermodyn. 2011, 43, 1557-1563. DOI:10.1016/j.jct.2011.05.015

49. Ž. Medoš, M. Bešter-Rogač, Langmuir 2017, 33, 7722-7731. DOI:10.1021/acs.langmuir.7b01700

50. A. Kroflič, B. Šarac, M. Bešter-Rogač, Acta Chim. Slov. 2012, $59,564-570$.
51. K. D. Danov, P. A. Kralchevsky, K. P. Ananthapadmanabhan, Adv. Colloid Interface Sci. 2014, 206, 17-45.

DOI:10.1016/j.cis.2013.02.001

52. D. Stigter, K. J. Mysels, J. Phys. Chem. 1955, 59, 45-51. DOI: $10.1021 / \mathrm{j} 150523 \mathrm{a} 014$

\section{Povzetek}

$\mathrm{Z}$ izotermno titracijsko kalorimetrijo (ITC) smo v temperaturnem območju med 15 in $55^{\circ} \mathrm{C}$ proučevali micelizacijo natrijevega dodecil sulfata (SDS) v vodi in vodnih raztopinah treh imidazolijevih ionskih tekočin (IL) $\mathrm{z}$ različnimi dolžinami stranskih verig, in sicer 1,3-dimetil imidazolijevega klorida $\left(\left[\mathrm{C}_{1} \mathrm{mim}\right] \mathrm{Cl}\right)$, 1-etil-3-metil imidazolijevega klorida $\left(\left[\mathrm{C}_{2} \mathrm{mim}\right] \mathrm{Cl}\right)$ ter 1-butil-3-metil imidazolijevega klorida $\left(\left[\mathrm{C}_{4} \mathrm{mim}\right] \mathrm{Cl}\right)$. Za primerjavo smo proučili tudi micelizacijo SDS $\mathrm{v}$ prisotnosti $\mathrm{NaCl}$. Eksperimentalne ITC podatke smo analizirali s pomočjo dvostopenjskega ravnotežnega modela, iz česar smo dobili vrednosti kritične micelne koncentracije $(\mathrm{cmc})$, agregacijskega števila $(n)$ ter vrednosti sprememb standardne toplotne kapacitete $\left(\Delta_{\mathrm{M}} c_{p}{ }^{\circ}\right)$, standardne entalpije $\left(\Delta_{\mathrm{M}} H^{\circ}\right)$, standardne entropije $\left(\Delta_{\mathrm{M}} S^{\circ}\right)$ in Gibbsove proste entalpije $\left(\Delta_{\mathrm{M}} G^{\circ}\right)$ za proces micelizacije. Ugotovili smo, da je micelizacija SDS v vseh proučevanih sistemih entropijsko voden proces pri nizkih temperaturah in entalpijsko voden proces pri visokih temperaturah. Predpostavimo lahko, da so $\mathrm{z}$ naraščajočim nepolarnim značajem ionskih tekočin interakcije z SDS bolj izražene, s čimer vrednosti $\Delta_{\mathrm{M}} H^{\circ}$ in $\Delta_{\mathrm{M}} G^{\circ}$ postanejo bolj negativne. Da bi pridobili več informacij o naboju micel, smo izvedli meritve električne prevodnosti in zeta-potenciala pri $25^{\circ} \mathrm{C}$. Zaradi močnejše interakcije in možnega vgrajevanja IL v micelno strukturo SDS je naboj micel bolj pozitiven. To se odraža v manj negativnih vrednostih zeta-potenciala v primerjavi s SDS v vodi, kar vodi do višjih vrednostih stopnje ionizacije micel zaradi večjega deleža natrijevih ionov v raztopini.

Except when otherwise noted, articles in this journal are published under the terms and conditions of the Creative Commons Attribution 4.0 International License 